DOI 10.15826/qr.2020.2.479

УДК 327.8:791.43/.45(73)

\title{
THE RED MACHINE: \\ THE DEHUMANIZATION OF THE COMMUNIST ENEMY IN AMERICAN COLD WAR CINEMA**
}

\author{
Oleg Riabov \\ St Petersburg State University, \\ St Petersburg, Russia
}

This article deals with the US Cold War cinematographic construction of the Soviet enemy. The researcher focuses on the means of dehumanising the communist enemy, external and internal, by equating it to a machine. The author applies Nick Haslam's dual model of dehumanization (2006), according to which dehumanization is visible in two main forms: animalistic, by associating members of the out-group with animals, and mechanistic, by associating them with a soulless machine. The materials used consist of US films from the "Long Fifties", in which Hollywood, equating the enemy to machines, developed three plots: the robotic existence of individuals in a totalitarian society; the transformation of Americans into zombies by communists by means of Soviet science; and the body snatching of Americans by an alien mind, an allegory of a future communist occupation of the USA. The article demonstrates that dehumanization was implemented by directly labeling the representatives of the communist world as robots and by attributing to them a lack of emotions, consciousness, will, individuality, initiative, warmth, love, friendship, creative abilities, and even the ability to smile. Such an image of the enemy implied a moral exclusion, treating them as an inanimate object unworthy of empathy, including in the event of their destruction. The author points out that the use of mechanistic dehumanization was very effective. Essentialization of the differences between "us" and "them" occurred: the symbolic border between them is presented as a boundary between living and nonliving. The image of mortal danger was created: the "Red Machine" is strong and merciless, it cannot be moved to pity, and so it is permissible to destroy it. This image contributed to the legitimation of power: the political opponents of the authorities are represented as internal enemies who are anxious to turn Americans into obedient executors of someone else's will and to deprive them of humanity. At the same time, the machine also has weaknesses, and it is possible to defeat it:

* This article is financially supported by the Russian Science Foundation, grant 18-18-00233 "Cinematographic Images of the Soviet and American Enemies in the Symbolic Politics of the Cold War: Comparative Analysis" (headed by O. V. Ryabov).

** Citation: Riabov, O. (2020). The Red Machine: The Dehumanization of the Communist Enemy in American Cold War Cinema. In Quaestio Rossica. Vol. 8, № 2. P. 536-550. DOI 10.15826/qr.2020.2.479.

Цитирование: Riabov O. The Red Machine: The Dehumanization of the Communist Enemy in American Cold War Cinema // Quaestio Rossica. Vol. 8. 2020. № 2. P. 536-550. DOI 10.15826/qr.2020.2.479.

(C) Riabov O., 2020

Quaestio Rossica • Vol. 8 • 2020 • № 2, p. 536-550 
since it is devoid of human creativity, it is clearly inferior to the free human spirit embodied in America.

Keywords: image of Russia; Cold War; US cinema; image of the enemy; dehumanization; propaganda.

Исследуется проблема конструирования образа советского врага кинематографом США периода холодной войны. Предметом анализа становятся способы дегуманизации коммунизма, внешнего и внутреннего, с использованием его сравнения с машиной. В основе методологии лежит концепция Ника Хэслема, согласно которой дегуманизация аутгруппы как полное или частичное отрицание человечности осуществляется в двух формах: анималистской при помощи сравнения людей с животными и механицистской за счет их уподобления неодушевленным механизмам. Источниками исследования являются американские фильмы «долгих пятидесятых», в которых Голливуд разрабатывал три сюжета: роботоподобное существование индивидов в тоталитарном обществе; превращение коммунистами американцев в зомби при помощи советской науки; похищение тел американцев инопланетным разумом как аллегория захвата США коммунизмом. Дегуманизация осуществлялась через прямую маркировку представителей коммунистического мира как роботов или сравнение их с машиной, а также путем атрибутирования им отсутствия эмоций, воли, индивидуальности, инициативы, теплоты в человеческих отношениях, любви, дружбы, творческих способностей. Такое изображение врага влекло за собой отношение к нему как к неодушевленной вещи, исключение его из моральной системы, отсутствие эмпатии, в том числе в случае его уничтожения. Использование механистической дегуманизации позволяло реализовались функции, которые был призван выполнять образ врага. Происходит эссенциализация отличий «своих» от «чужих»: символическая граница между ними представлена как граница между живым и неживым. Создается образ смертельной опасности: «красная машина» сильна, ее невозможно разжалобить, поэтому допустимо ее уничтожать. Оппоненты власти представлены как внутренние враги, стремящиеся превратить американцев в исполнителей чужой воли и лишить их человечности. Но «машина» лишена творческих способностей, она уступает свободному человеческому духу, воплощением которого является Америка, поэтому ее возможно победить.

Ключевые слова: образ России; холодная война; кинематограф США; образ врага; дегуманизация; пропаганда.

When Russians hear the words "Red Machine" today, their hearts, especially those of hockey fans, are filled with pride. This phrase has a special meaning. It refers to the Russian hockey team, which inherited the traditions of the USSR national team: its energy, team play, mutual assistance, and victory. However, the description of the Soviet team as a "Red Machine" 
appeared in the West during the Cold War, in the 1970s and 1980s [Martin], and included a slightly different set of meanings: the USSR national team was credited not only with team spirit, collectivism, and power, but also with certain robotic features. Commenting on the defeat of the US national team at the pre-Olympic tournament in 1980, its captain Mike Eruzione said of the Soviet hockey players: "They were like robots. When they scored a goal, they never smiled. I don't think I ever saw them smile" [Do You Believe in Miracles]. This comparison helped to draw a symbolic border between "us" and "them": indeed, the right of the latter to be considered as people was challenged. In other words, this was one of the ways in which the enemy was dehumanized. The image of the communist enemy constructed by American Cold War discourse has been studied for several decades; in particular, different scholars have demonstrated various ways of creating this image [e. g. Sharp; Robin; Давыдова]. However, researchers have not yet addressed the comparison of the enemy with a machine.

I will use cinematography to try to analyze this phenomenon. Cinema was one of the main theaters of the cultural Cold War. On both sides of the Iron Curtain, leading directors, actors, and scriptwriters were involved in the "struggle for hearts and minds". Cinema, which combined three forms of propaganda (visual images, narration, and sounds), served as a very effective tool in constructing the image of the enemy (for more detailed information on the cinematic Cold War, see, [Strada, Troper; Kenez; Shaw; Shaw, Youngblood; Riabov; Федоров]).

The purpose of this article is therefore to analyze how dehumanization of enemy number one was conducted in US Cold War cinema by comparing external and internal communism with a machine. The sources of the research are films from the so-called Long Fifties (1946-1963), considered to be the most dangerous period of the Cold War, when the prospect of a full-blown nuclear war looked quite real. The first part of the article will focus on the methodological foundations of research into dehumanization as a method for constructing the image of the enemy. Then, the ways in which the image of the communist enemy was constructed in American Cold War discourse will be analyzed. Finally, the comparison of the enemy with a machine in cinema will be investigated: I will examine the forms and techniques of dehumanization, as well as the attitude towards the communist enemy as determined by the created images.

\section{The enemy image and dehumanization}

It is important, however, to highlight the main functions of the image of the enemy. First of all, we would like to mark out the function of strengthening positive collective identity, which is manifested with the help of representing the enemy as being as different from "us" as possible and by drawing a firm and natural symbolic border between them. The mobilization function requires the creation of an image of mortal danger for each member of the community; the enemy must therefore terrify. The function of legitimizing violence involves portraying the enemy in such a way as to justify negative 
feelings toward them, violence against them, or even their elimination. The function of legitimizing power and the social and political order is associated with representations of rulers as reliable defenders from the enemy. The political opposition is therefore labeled as internal enemies and accomplices of external enemies. Finally, the function of predicting victory involves the justification of one's own military superiority and the image of the enemy as weak and vulnerable [Рябов, 2019, с. 85].

Consequently, an effectively constructed image of the enemy is supposed to evoke a feeling of mortal danger, hatred for the enemy, a willingness to eliminate them, a sense of moral superiority over them, and laughter. The enemy should be depicted comical so that "we" do not lose confidence in the final victory [Aho; Keen; Harle; Porshneva].

The enemy should be portrayed as the Other and as something worse. So, one of the objectives of studying this image is to analyze the ways in which its othering and inferiorization are portrayed. Symbolic borders that exclude "them" are drawn using various discourses, including political, moral, axiological, historical, gender, anthropological, confessional, ethnic, racial, and aesthetic ones. At the same time, if the methodology of intersectionality is used, it is necessary to take into account the fact that the differentiating categories of class, race, gender, ethnicity, national, and civilizational affiliation interact with each other and create a system of social hierarchy [Crenshaw]. Obviously, this situation can also be extrapolated to international relations: the political otherness of the opponent in the international arena will be strengthened due to moral, confessional, and gender othering.

The present paper deals with the anthropological type of discourse associated with efforts to interpret the truly human. Dehumanization as a complete or partial denial of humanity is one of the elements of anthropological discourse in military propaganda. Nick Haslam, in an article which reviews the works of many scholars on dehumanization, substantiates the idea that dehumanization depends on an understanding of humanity. The author proceeds from the trichotomy "man - animal - machine" and proposes that two sets of characteristics attributable to man should be distinguished: uniquely human $(\mathrm{UH})$ ones, which differentiate man from animals, and human nature (HN) ones, which separate man from machine [Haslam, p. 255-257]. UH characteristics involve refinement, civility, morality, and higher cognition. HN characteristics include cognitive flexibility, emotionality, vital agency, and warmth.

The denial of these characteristics is used in two forms of dehumanization: animalistic and mechanistic, respectively. In the former, representatives of the out-group are endowed with the following features: they are coarse, uncultured, lacking in self-control, and unintelligent. They are declared deprived of moral sensibility and cognitive capacity. A more nuanced means of animalization is infra-humanization [Haslam], which is studied in the works of J. P. Leyens and his colleagues. In particular, they have shown that people commonly attribute more uniquely human "secondary" emotions (including love, hope, regret, nostalgia) to the in-group 
than to out-groups but do not deny the latter the primary emotions that we share with other animals (e. g. joy, anger, sadness) [e. g. Leyens et al.].

The attribution of such traits contributes to a certain attitude towards the representatives of out-groups: they must be governed because they are incapable of self-control; communication with them does not imply an equal dialogue, so manipulation is permissible; their objectification occurs, so it is acceptable to treat them not as an end, but simply as a means [Haslam, p. 254, 260].

The mechanistic form of dehumanization includes the denial that out-group representatives have traits like agency, subjectivity, individuality, emotionality, inter-personal warmth, empathy, and flexible thinking [Ibid.]. The ways these characteristics manifest themselves in cinematic representations will be considered further.

\section{Dehumanizing the Cold War enemy}

The dehumanization of the enemy was widely used by the propaganda machines of both superpowers. First of all, this is true in relation to the animalistic form of dehumanization. The comparison of the enemy with animals occupied a prominent place in both Soviet and American Cold War discourses [Bonnell; Riabov] ${ }^{1}$. In American representations of the USSR, a significant role was given to the "Russian bear" as one of the embodiments of barbarism and brutal force [Рябов, 2013]. To a much greater extent, this dehumanization took shape when the USSR was attributed with characteristics that contributed to the association of the country and its population with animals. However, this should be the subject of a specific study.

If comparing the enemy with animals was a common practice, then drawing a parallel between the enemy and a machine was much less widespread, although mechanical dehumanization as a method of military propaganda appeared long before the Cold War. S. Keen identifies several models of the enemy, one of which is comparing the enemy with a soulless machine. In particular, he shows that during the First World War, one of the images of Triple Entente propaganda was German militarism as the mechanical monster Frankenstein [Keen, p. 147]. The accusations that German culture idolized technology were also popular in the Russian propaganda of the time [Jahn, p. 165]. Mechanistic dehumanization was also used in the USSR. For example, in Alexander Nevsky (1938), a film dir. by Sergei Eisenstein, German knights are shown as robots, and this visual mechanization is complemented by Sergei Prokofiev's music. The image of Nazi Germany as a monstrous machine was also prominent in Dmitri Shostakovich's Symphony No. 7 titled Leningrad (1942).

It is obvious that, in addition to the patterns noted above, there must be other reasons for comparing a country with a machine. In the case of Germany, the use of this comparison was not particularly surprising because

\footnotetext{
${ }^{1}$ See the film The Beast of Yucca Flats (dir. by Coleman Francis, 1961), in which a representative of the communist world literally turns into a beast [Hendershot].
} 
the stereotype of a German contains such features as rationality, order, discipline, and punctuality. The country itself is associated with a high level of technology. But how did it happen that the Russian bear, mighty but lagging far behind the "civilized world", was suddenly turned into the Red Machine in Cold War discourse?

Even before World War II, rationalism, the sacralization of science, and the criticism of religion and bourgeois morality were part of the image of communism, and all of these contributed to its association with a machine. Far more prevalent, however, was the image of a totalitarian society as a mechanism in which man is assigned the part of $\operatorname{a~cog}^{2}$. It is worth remembering that even in Ninotchka (dir. by Ernst Lubitsch, 1939), the main character, a convinced communist, speaks of herself with pride as "a tiny cog in the great wheel of evolution". This image of a Soviet citizen as a small cog in a huge machine was subsequently used by Edgar Hoover, the first head of the FBI, in his book Masters of Deceit (1958). He wrote that the Communist Party believed that "man can be completely redesigned from a child of God into a soulless social cog" through "discipline, education, the Party press, recreation, literature, organizational structure, the arts" [quoted in: Dunne, p. 58].

\section{The mechanistic dehumanization of the communist enemy}

Before turning to how mechanistic dehumanization was performed in cinema, we should first describe the most distinctive way in which films compared the representatives of communist society to a machine. Depending on how the source of dehumanization is presented, three plots in the cinema of the "Long Fifties" can be identified.

The first plot is connected with cinematic representations of the USSR or a society which becomes a victim of Soviet conquest. Here, the system of state terror and totalitarian propaganda make people similar to robots. We will focus on two films: Silk Stockings (dir. by Rouben Mamoulian, 1957) and Red Nightmare (dir. by George Waggner, 1962). The first is a remake of Ninotchka. It is the story of a convinced communist Nina, who goes on a party mission to Paris only to be charmed by an American man and the abundance of capitalist society. The second film, released by the US Department of Defense, shows the communist enslavement of the USA through the prism of an average American family. Jerry Donovan is $100 \%$ American who, however, does not fully understand that the fight against communism is the responsibility of all US citizens. This is why the filmmakers send him a nightmare in which America is placed under the heel of communism and everything in his country changes according to the Soviet model. Outraged, Donovan tries to fight the new authori-

2 This is how Arthur Schlesinger Jr., in his influential book of the late 1940s The Vital Center: The Politics of Freedom (1949), describes a person in a totalitarian society: "tightlipped, cold-eyed, unfeeling, uncommunicative men, as if badly carved from wood, without humor, without tenderness, without spontaneity, without nerves" [quoted in: Alpers, p. 280]. 
ties and is sentenced to be shot. When our hero wakes up, he is sure to become a completely different person.

The second plot depicts the transformation of freedom-loving Americans into zombies by communists through science and brainwashing. The most famous movie developing this plot is The Manchurian Candidate (dir. by John Frankenheimer, 1962) (fig. 1). It tells us about Sergeant Raymond Shaw, who is captured during the Korean War. He is programmed by a group of Soviet and Chinese psychologists under the guidance of the secret services in such a way that he becomes an obedient executor of orders from communist agents in the USA who were headed by his mother Eleanor Iselin. His main mission upon returning to the United States is to kill the Republican presidential candidate so that his stepfather can take the presidential office, allowing him to put forward a policy in the best interests of the Kremlin.

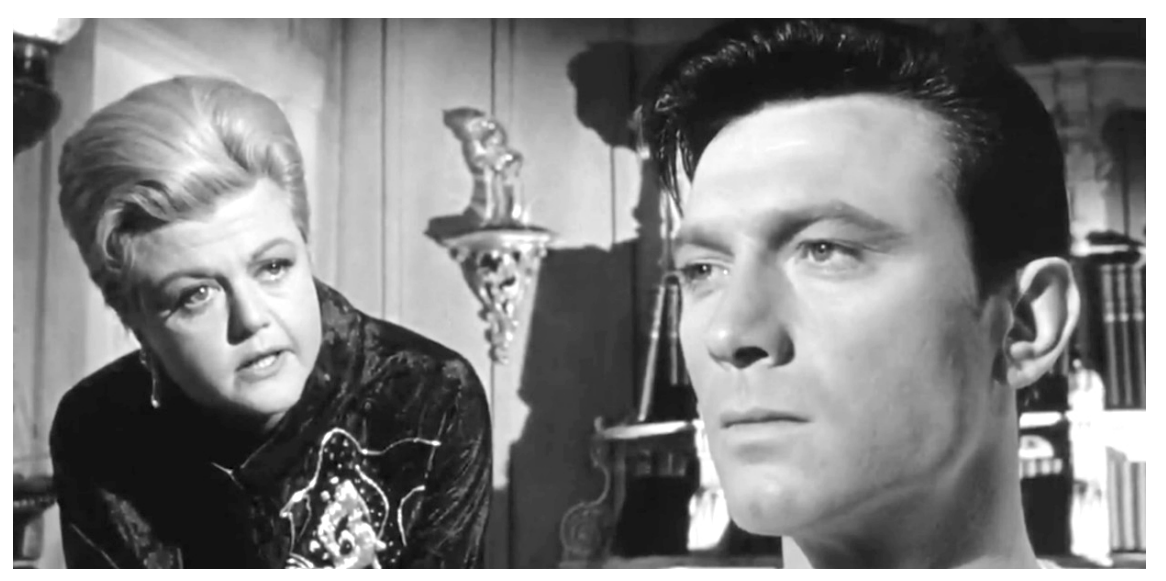

1. Angela Lansbury as Eleanor Iselin and Laurence Harvey as Raymond Shaw in a scene from The Manchurian Candidate

Lastly, the third plot is connected with the invasion of aliens and their attempts to seize power in the USA. Most scholars believe that these scifi filmmakers, as well as their audience, perceived alien aggression as an allegory for communist invasion [e. g. Shaw, p. 50]. The ability of aliens to capture the consciousnesses of Americans and snatch bodies by taking human form looked especially scary. This also played an important role in creating the image of the "Red Menace". The danger may come from everywhere: there may be a deadly merciless enemy in the body of the person whom you consider your nearest and dearest. Among the most famous films based on such a plot are Invaders from Mars (dir. by William Cameron Menzies, 1953), Invasion of the Body Snatchers (dir. by Don Siegel, 1956) (fig. 2), and I Married a Monster from Outer Space (dir. by Gene Flower Jr., 1958) (fig. 3). 


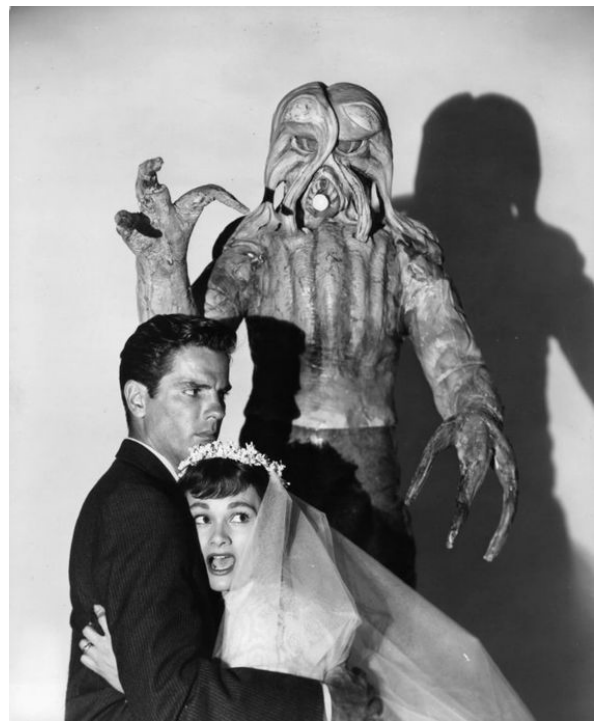

2. Promotional picture from I Married a Monster from Outer Space

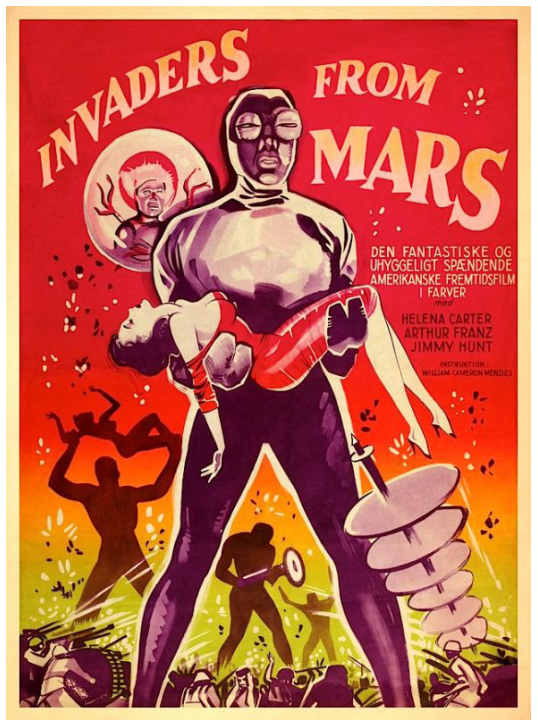

3. Poster for Invaders from Mars

It should be emphasized that, in addition to mechanistic dehumanization, these films played an important role in strengthening the symbolic border between "us" and "them", as they showed the absolute alienness of communism not only to humans, but also to everything of this world.

The mechanistic form of dehumanization included a direct comparison of representatives of the communist world with robots. For example, in Silk Stockings, the American Steve Canfield proudly says about the transformation of Nina, who is in love with him and has lost her communist illusions, that he thought he "saw a carefully trained robot turn into a woman." An indirect form of dehumanization was used to endow communists with robotic features. Haslam emphasizes that the mechanistic form of dehumanization is expressed through representatives of out-groups being shorn of emotions [Haslam, p. 258-260]. In the films under study, the villainous characters do not show love, compassion, anger, hatred, or rage. In The Manchurian Candidate, Raymond kills his wife and father-in-law unemotionally, just obeying the orders of his Soviet masters. The absence of emotions - either positive or negative - in such heroes is especially noticeable against the background of the increased emotionality of their antagonists, Americans who react very violently towards the established totalitarian regime. Jerry, the hero of Red Nightmare, is indignant that the communists have turned the church into a museum of atheism and puts up a fight there. Meanwhile, his opponents are extremely calm: even when they shoot him, they do not show any specific emotions. Equally unemotional are his wife and children, who have been subjected to communist indoctrination. 
Family relations on both sides of the Iron Curtain were an essential part in the struggle for hearts and minds [May]. In American anti-communism, the Bolsheviks had been accused of wanting to abolish the family, communalizing their wives and entrusting their children from infancy to the care of the state, since the 1920s. Numerous cases of children informing on their parents were demonstrative of the lack of family warmth [Peacock, p. 53] $]^{3}$. The dehumanization practices under study helped to demonstrate that communists simply do not need a family, since they do not and cannot have a need for emotional bonds.

The relationships of members of the communist world are another aspect of the representations of the "Red Machine". Like insects, they interact perfectly with each other, but there are no emotional bonds between them at all. Friendship has no value, they are absolutely indifferent toward each other. It is never shown that they, for example, express any regret for the death of their comrade or want to avenge themselves on capitalist enemies. They do not hesitate to kill a wounded comrade if they become a burden.

A cinematic image of robot-like people is created through facial expressions - or rather, their absence. In all the films under study, the faces of the

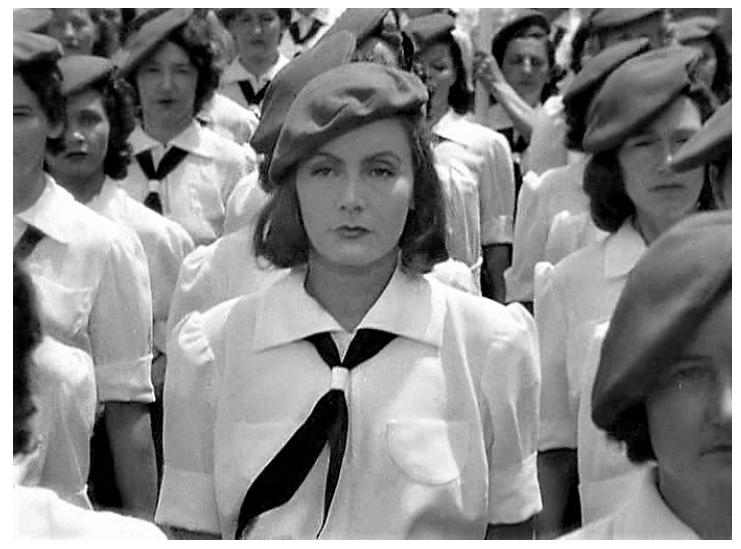

4. Greta Garbo as Nina Yakushova in a scene from Ninotchka members of the communist world are motionless. The canon of such a model of communist facial expressions was established in Ninotchka (fig. 4). Greta Garbo was perfect for this role because she had had the reputation of an actress who never smiled. Consequently, her laugh in the film ("Garbo laughs!" became the slogan of the advertising campaign for the movie) was a sign of a communist robot returning to a natural human state. It is of critical importance that this happened thanks to the love of a Soviet woman for a Western man.

The theme of love between an American man and a Soviet woman, which many Hollywood films have been dedicated to since the release of Ninotchka [Рябов 2013], was in great demand. Communist women were distinguished by the complete absence of romanticism, which they regard as impractical bourgeois stupidity. Here are typical dialogues featuring Nina from Silk Stockings. To the question of her boss, "You are a music

${ }^{3}$ It is significant that comparing Soviet schoolchildren with robots was very common in the period analyzed [Peacock, p. 51-60]. 
lover?", she answers, "Music is essential for parades". When she receives an answer from Steve that his ties are made of silk, she notes, "Silk should be used for parachutes". This emotional poverty reveals itself in relation to love. In the film Invasion of the Body Snatchers, one of the aliens explains to the main protagonist, "There's no need for love... Love, desire, ambition, faith - without them, life's so simple, believe me."

One further feature in the portrayal of communists is the lack of personality, which manifests itself both in the absence of individuality and of one's own will. The world that the aliens from Invasion of the Body Snatchers want to create is a society free not only of trouble ("an untroubled world"), but also of individual differences. Absolute obedience to the orders of leaders is another distinctive feature of communists, and military discipline characterizes both men and women (for example, Nina in Silk Stockings).

Communists' cognitive abilities are also associated with robot-like behavior. These abilities are characterized by rigidity, readiness to perform programmed actions, and an inability to think creatively. They are also easily outwitted. In this regard, the scene from Invasion of the Body Snatchers where Miles and Becky flee from the aliens who have assumed human appearance is illustrative. The filmmakers focus on how ridiculously the pursuers behave and how they get in the way of each other. Such bewilderment is so clearly shown on their faces that the viewer is in no doubt that the fugitives will be able to escape.

Haslam notes that dehumanizing images of an out-group not only shape its assessment, but also program the attitude towards its members: a lack of empathy, moral exclusion, and the acceptability of destruction [Haslam, p. 262]. Almost all of the films under study contain scenes of the murder of automaton-esque communists. However, there is no sympathy from the films' characters (or their makers) in these scenes. The commandment "Thou shalt not kill!" does not apply to them. The scene from Invasion of the Body Snatchers where Becky screams in horror is typical: she is worried about a dog that might be run down by car. A minute before this scene, she stabs one of the aliens without the slightest regret.

Finally, it should be noted that mechanistic dehumanization manifested itself throughout the Cold War era. The duel of the man symbolizing America and the machine symbolizing the USSR became a key event in many Hollywood blockbusters of the 1980s, including Red Dawn (dir. by John Milius, 1984), Rambo III (dir. by Peter MacDonald, 1988), and Firefox (dir. by Clint Eastwood, 1982) [Palmer, p. 214, 219]. The best-known case of the man vs. machine opposition is the confrontation between the main characters of the film Rocky IV (dir. by Sylvester Stallone, 1985). Ivan Drago, Rocky's opponent in a boxing match, is perceived as a merciless Soviet machine. In the crucial moment of their bout, the coach, in order to inspire confidence in Rocky, shouts: "You hurt him! You see? You see? He's not a machine. He's a man!" The image of Drago is typical of mechanistic dehumanization during the Cold War: he is shorn of emotions, does not feel any pain, and scarcely utters a word [Shaw, Youngblood, p. 160, 168]. Moreover, 
the face of Dolph Lundgren, who plays the role of Drago, is devoid of facial expressions; unlike Stallone's hero, he does not smile (fig. 5).

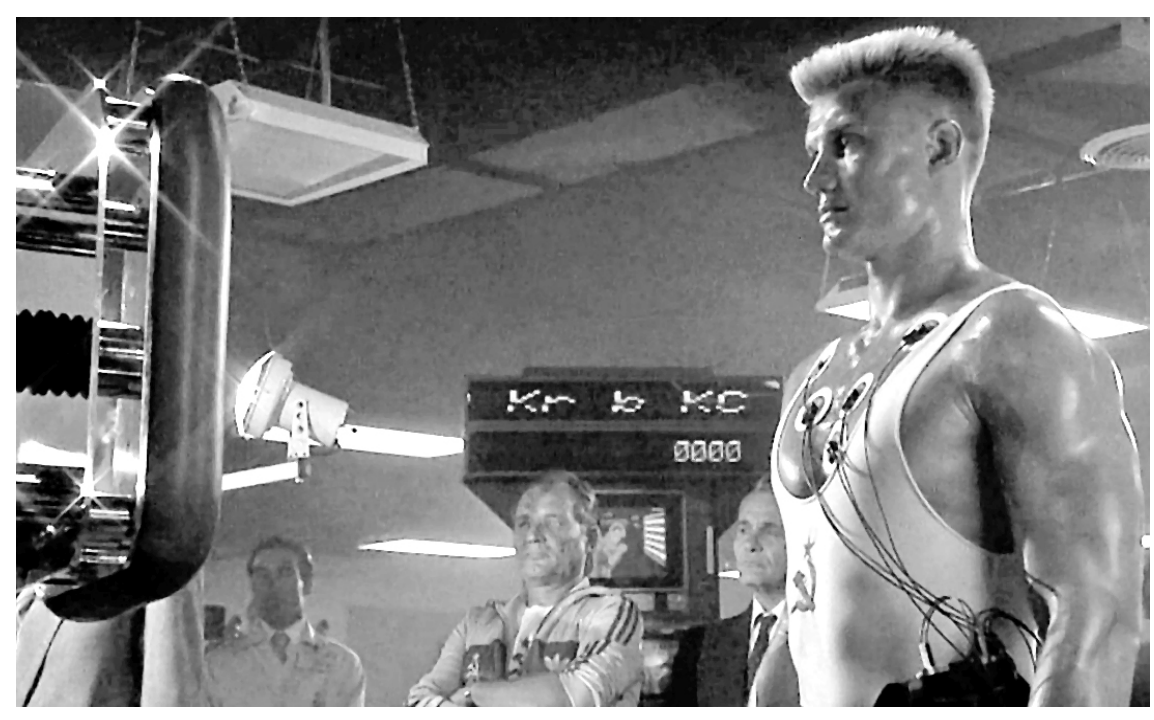

5. Dolph Lundgren as Ivan Drago in a scene from Rocky IV

This last fact deserves special attention. An unwillingness to smile is an integral part of the Western stereotype of Russians. It should be emphasized here that this feature can be interpreted as a sign not only of a lack of courtesy and amicability, but also of the robot-like features under study. J. Sharp cites an excerpt from an article in The Readers Digest published in 1985. It described a twelve-year-old Russian who came to live in America. The boy's American teacher was quoted as saying, "Walter has changed from a robot to a kid learning to laugh" [Sharp, p. 132-133]. The scholar emphasizes that a smile was an important diacritic for distinguishing members of the free world from the robotic inhabitants of the world behind the Iron Curtain [Ibid., p. 117-119].

Similarity to a machine is one of the forms of dehumanization, along with the animalistic form, used by American cinema in relation to the internal and external communist enemy. Comparing the enemy with a machine, Hollywood developed three plots: the robotic existence of individuals in a totalitarian society; the transformation of Americans into zombies by communists using Soviet science; and the body snatching of Americans by an alien mind as an allegory of the occupation of the USA by communism.

Mechanistic dehumanization was implemented through direct labeling of the representatives of the communist world as robots and through attributing to them the lack of emotions, consciousness, will, individuality, 
initiative, warmth in human relations, love, friendship, creativity, and, finally, the ability to smile. Such an image of the enemy implied a moral exclusion, treating them as an inanimate object unworthy of empathy, including in the event of their destruction.

This sort of dehumanization was very effective. The essentialization of differences between "us" and "them" occurs: the symbolic border between them is presented as the boundary between living and nonliving. The image of mortal danger is created: the "Red Machine" is strong and merciless, it cannot be moved to pity, so it is permissible to destroy it. At the same time, the machine also has weaknesses: it is vulnerable and can be defeated, since it is devoid of human creativity. Opponents of the government are represented as internal enemies who are anxious to turn freedom-loving Americans into obedient executors of someone else's will and to deprive them of humanity.

The observed dehumanization practices were aimed not only at obtaining advantages in the strugglefor hearts and minds when confronting the USSR; the communist Other was also a projection of the fears of Americans themselves. The "Long Fifties" was when new trends in the development of American society appeared, which some interpreted as a shift away from traditional values. For example, pastor Billy Graham regarded the establishment of mass society in the USA as dangerous dehumanization through the transformation of America into a civilization of robots manipulated by the media [Stevens, p. 176]. Additionally, it must be kept in mind that in the post-war USA, the rapid development of science and technology was often perceived as hostile to humanity ${ }^{4}$. First of all, this distrust was associated with the fear of the nuclear bomb and new types of weapons; space exploration also fed a fear of a war of the worlds and alien invasion (and the success of the USSR in the Space Race was far from being universally admired in the USA). Finally, it was associated with the development of psychology and new ways of controlling human consciousness [Robin]. Consequently, the communist threat and distrust of science complemented each other.

It should be emphasized that the films analyzed are interesting not only from a historical viewpoint - the images created in them have been updated in the modern American policies, both domestic and foreign. One of the most noticeable cases is the interpretation of the Donald Trump phenomenon through the prism of images from The Manchurian Candidate. A few months before the US presidential election in 2016, The New York Times published an article entitled Donald Trump, the Siberian Candidate by Paul Krugman, a Nobel Prize winner in Economics. This piece accused Trump of being supervised from abroad [Krugman]. This comparison was actively supported by representatives of the Democratic Party and their loyalists. This association of the politician with the heroes of the film and its plot, placing the perception of current Russian-American relations in the framework of one of the most dramatic episodes of the Cold War, strengthened accusations

\footnotetext{
${ }^{4}$ It is no coincidence that the mad scientist as a movie villain became widespread at that time [Frayling].
} 
that Russia was interfering in the elections, reduced Trump's legitimacy, and represented the politician and his supporters as zombies acting at the behest of the Kremlin. The idea that Russia is sowing discord in American society and is manipulating the choice of millions of US citizens has not significantly departed from the ideas of the "Long Fifties" about the ability of a communist enemy to take over the consciousness of freedom-loving Americans. Certainly, not everyone in the USA shares this idea. Moreover, even in the Cold War, not everyone trusted the representations of the enemy produced by Hollywood: otherwise, The Russians are Coming! The Russians are Coming! (dir. by Norman Jewison), with its distinguished "re-humanization" of the Soviet Other, would not have been released in 1966 and nominated for the Academy Award the next year ${ }^{5}$.

\section{Список литературы}

Давыдова О. С. Иллюзорная идеология: как неигровое кино США превратилось в орудие холодной войны // Terra Aestheticae. 2019. № 2. С. 82-105.

Рукавишников B. О. Холодная война, холодный мир: общественное мнение в США и Европе об СССР/России, внешней политике и безопасности Запада. М. : Академ. проект, 2005. $863 \mathrm{c}$.

Рябов O. B. «From Russia with love»: образ СССР в гендерном дискурсе американского кинематографа (1946-1963 гг.) // Общественные науки и современность. 2013. № 5. C. 166-176.

Рябов О. В. Женщины нацистской Германии в зеркале советской карикатуры (на материале журнала «Крокодил») // Урал. ист. вестн. 2019. № 3. С. 84-92. DOI 10.30759/1728-9718-2019-3(64)-84-92.

Федоров А. В. Отражения: Запад о России / Россия о Западе. Кинообразы стран и людей. М. : Информация для всех, 2017. 389 с.

Aho J. A. This Thing of Darkness: A Sociology of the Enemy. Seattle : Univ. of Washington Press, 1994. 224 p.

Alpers B. L. Dictators, Democracy, and American Public Culture: Envisioning the Totalitarian Enemy, 1920s-1950s. Chapel Hill : Univ. of North Carolina Press, 2003. 405 p.

Bonnell V. E. Iconography of Power: Soviet Political Posters under Lenin and Stalin. Berkeley : Univ. of California Press, 1997. 363 p.

Crenshaw $K . W$. Mapping the Margins: Intersectionality, Identity Politics, and Violence against Women of Color // Stanford Law Rev. 1991. Vol. 43. No. 6. P. 1241-1299.

Do You Believe in Miracles? The Story of the 1980 U. S. Hockey Team (2001 TV Movie) // YouTube : [website]. URL: https://www.youtube.com/watch?time continue $=29 \& \mathrm{v}=\mathrm{CDBuPpalXI} 4$ (mode of access: 12.12.2019).

Dunne M. W. A Cold War State of Mind : Brainwashing and Postwar American Society. Amherst : Univ. of Massachusetts Press, 2013. 300 p.

Frayling C. Mad, Bad and Dangerous? The Scientist and the Cinema. L. : Reaktion Books, 2006. 240 p.

Harle $V$. The Enemy with a Thousand Faces: The Tradition of the Other in Western Political Thought and History. Westport : Praeger, 2000. 232 p.

Haslam N. Dehumanization: An Integrative Review // Personality and Social Psychology Rev. 2006. Vol. 10. No. 3. P. 252-264. DOI 10.1207/s15327957pspr1003_4.

Hendershot C. Anti-Communism and Ambivalence in "Red Planet Mars", "Invasion USA", and "The Beast of Yucca Flats" // Science Fiction Studies. 2001. Vol. 28. P. 246-260. Jahn H. F. Patriotic Culture in Russia during World War I. Ithaca : Cornell Univ. Press, 1995. 229 p.

Keen S. Faces of the Enemy: Reflections of the Hostile Imagination. San Francisco : Harper \& Row, 1986. 199 p.

${ }^{5}$ On the dynamics of US citizens' perception of the USSR see: [Рукавишников]. 
Kenez P. The Picture of the Enemy in Stalinist Films // Insiders and Outsiders in Russian Cinema / ed. by S. M. Norris, Z. M. Torlone. Bloomington : Indiana Univ. Press, 2008. P. 96-112.

Krugman P. Donald Trump, the Siberian Candidate // New York Times : [website]. 2016. 7 July. URL: https://www.nytimes.com/2016/07/22/opinion/donald-trump-thesiberian-candidate.html (mode of access: 10.09.2019).

Leyens J. P., Demoulin S., Vaes J., Gaunt R., Paladino M. P. Infra-Humanization: The Wall of Group Differences // Social Issues and Policy Rev. 2007. Vol. 1. No. 1. P. 139-172. DOI 10.111//j.1751-2409.2007.00006.x.

Martin L. The Red Machine: The Soviet Quest to Dominate Canada's Game. Toronto : Doubleday, 1990. 293 p.

May E. T. Homeward Bound: American Families in the Cold War Era. N. Y. : Basic Books, 1988. 284 p.

Palmer W. J. The Films of the Eighties: A Social History. Carbondale : Southern Illinois Univ. Press, 1993. 335 p.

Peacock M. Innocent Weapons: The Soviet and American Politics of Childhood in the Cold War. Chapel Hill : Univ. of North Carolina Press, 2014. 304 p.

Porshneva O. Image of the German Enemy as Perceived by Russian Army Soldiers during World War I // Quaestio Rossica. Vol. 1. 2014. No. 1. P. 79-93. DOI 10.15826/ qr.2014.1.024.

Riabov O. Gendering the American Enemy in Early Cold War Soviet Films (1946-1953)//

J. of Cold War Studies. 2017. Vol. 19. No. 1. P. 193-219. DOI 10.1162/JCWS_a_00722.

Robin R.T. The Making of the Cold War Enemy: Culture and Politics in the MilitaryIntellectual Complex. Princeton : Princeton Univ. Press, 2003. 296 p.

Sharp J. P. Condensing the Cold War: Reader's Digest and American Identity. Minneapolis : Univ. of Minnesota Press, 2000. 232 p.

Shaw T. Hollywood's Cold War. Amherst : Univ. of Mass. Press, 2007. 352 p.

Shaw T., Youngblood D. Cold War Sport, Film, and Propaganda: A Comparative Analysis of the Superpowers // J. of Cold War Studies. Vol. 19. 2017. No. 1. P. 160-192. DOI $10.1162 /$ JCWS a 00721 .

Stevens J. W. God-Fearing and Free: A Spiritual History of America's Cold War. Cambridge, MA : Harvard Univ. Press, 2010. 448 p.

Strada M. J., Troper H. R. Friend or Foe? : Russians in American Film and Foreign Policy, 1933-1991. Lanham : Scarecrow Press, 1997. 278 p.

\section{References}

Aho, J. A. (1994). This Thing of Darkness: A Sociology of the Enemy. Seattle, Univ. of Washington Press. 224 p.

Alpers, B. L. (2003). Dictators, Democracy, and American Public Culture: Envisioning the Totalitarian Enemy, 1920s-1950s. Chapel Hill, Univ. of North Carolina Press. 405 p.

Bonnell, V. E. (1997). Iconography of Power: Soviet Political Posters under Lenin and Stalin. Berkeley, Univ. of California Press. 363 p.

Crenshaw, K. W. (1991). Mapping the Margins: Intersectionality, Identity Politics, and Violence against Women of Color. In Stanford Law Rev. Vol. 43. No. 6, pp. 1241-1299.

Davydova, O. S. (2019). Illyuzornaya ideologiya: kak neigrovoe kino SShA prevratilos' v orudie Kholodnoi voiny [Elusive Ideology: How American Nonfiction Films Became a Cold War Weapon]. In Terra Aestheticae. No. 2, pp. 82-105.

Do You Believe in Miracles? The Story of the 1980 U. S. Hockey Team (2001 TV Movie). (2001). In YouTube [website]. URL: https://www.youtube.com/watch?time_ continue $=29 \& \mathrm{v}=\mathrm{CDBuPpalXI} 4$ (mode of access: 12.12.2019).

Dunne, M. W. (2013). A Cold War State of Mind. Brainwashing and Postwar American Society. Amherst, Univ. of Massachusetts Press. 300 p.

Fedorov, A. V. (2017). Otrazheniya: Zapad o Rossii / Rossiya o Zapade. Kinoobrazy stran $i$ liudei [Reflections: The West about Russia / Russia about the West. Cinematic Images of People and Countries]. Moscow, Informatsiya dlya vsekh. 389 p.

Frayling, C. (2006). Mad, Bad and Dangerous? The Scientist and the Cinema. L., Reaktion Books. 240 p. 
Harle, V. (2000). The Enemy with a Thousand Faces: The Tradition of the Other in Western Political Thought and History. Westport, Praeger. 232 p.

Haslam, N. (2006). Dehumanization: An Integrative Review. In Personality and Social Psychology Rev. Vol. 10. No. 3, pp. 252-264. DOI 10.1207/s15327957pspr1003 4.

Hendershot, C. (2001). Anti-Communism and Ambivalence in "Red Planet Mars", "Invasion USA", and "The Beast of Yucca Flats". In Science Fiction Studies. Vol. 28, pp. 246-260.

Jahn, H. F. (1995). Patriotic Culture in Russia during World War I. Ithaca, Cornell Univ. Press. 229 p.

Keen, S. (1986). Faces of the Enemy: Reflections of the Hostile Imagination. San Francisco, Harper \& Row. 199 p.

Kenez, P. (2008). The Picture of the Enemy in Stalinist Films. In Norris, S. M., Torlone, Z. M. (Eds.). Insiders and Outsiders in Russian Cinema. Bloomington, Indiana Univ. Press, pp. 96-112.

Krugman, P. (2016). Donald Trump, the Siberian Candidate. In New York Times [website]. 7 July. URL: https:/www.nytimes.com/2016/07/22/opinion/donald-trump-thesiberian-candidate.html (mode of access: 10.09.2019).

Leyens, J. P., Demoulin, S., Vaes, J., Gaunt, R., Paladino, M. P. (2007). InfraHumanization: The Wall of Group Differences. In Social Issues and Policy Rev. 2007. Vol. 1. No. 1, pp. 139-172. DOI 10.1111/j.1751-2409.2007.00006.x.

Martin, L. (1990). The Red Machine: The Soviet Quest to Dominate Canada's Game. Toronto, Doubleday. 293 p.

May, E. T. (1988). Homeward Bound: American Families in the Cold War Era. N. Y., Basic Books. 284 p.

Palmer, W. J. (1993). The Films of the Eighties: A Social History. Carbondale, Southern Illinois Univ. Press. 335 p.

Peacock, M. (2014). Innocent Weapons: The Soviet and American Politics of Childhood in the Cold War. Chapel Hill, Univ. of North Carolina Press. 304 p.

Porshneva, O. (2014). Image of the German Enemy as Perceived by Russian Army Soldiers during World War I. In Quaestio Rossica. Vol. 1. No. 1, pp. 79-93. DOI 10.15826/ qr.2014.1.024.

Riabov, O. (2013). "From Russia with Love": obraz SSSR v gendernom diskurse amerikanskogo kinematografa (1946-1963 gg.) ["From Russia with Love": The Image of the USSR in the Gender Discourse of American Cinema (1946-1963)]. In Obshchestvennye nauki i sovremennost'. No. 5, pp. 166-176.

Riabov, O. (2017). Gendering the American Enemy in Early Cold War Soviet Films (1946-1953). In J. of Cold War Studies. Vol. 19. No. 1, pp. 193-219. DOI 10.1162/ JCWS a 00722.

Riabov, O. V. (2019). Zhenshchiny natsistskoi Germanii v zerkale sovetskoi karikatury (na materiale zhurnala "Krokodil") [Women of Nazi Germany in the Mirror of the Soviet Caricatures (Materials from the "Crocodile" Magazine)]. In Ural'skii istoricheskii vestnik. No. 3, pp. 84-92. DOI 10.30759/1728-9718-2019-3(64)-84-92.

Robin, R. T. (2003). The Making of the Cold War Enemy: Culture and Politics in the Military-Intellectual Complex. Princeton, Princeton Univ. Press. 296 p.

Rukavishnikov, V. O. (2005). Kholodnaya voina, kholodnyi mir: obshchestvennoe mnenie v SShA i Evrope ob SSSR/Rossii, vneshnei politike $i$ bezopasnosti Zapada [Cold War, Cold Peace: US and European Public Opinion on the USSR/Russia, Foreign Policy and Security of the West]. Moscow, Akademicheskii proekt. 863 p.

Sharp, J. P. (2000). Condensing the Cold War: Reader's Digest and American Identity. Minneapolis, Univ. of Minnesota Press. 232 p.

Shaw, T. (2007). Hollywood's Cold War. Amherst, Univ. of Mass. Press. 352 p.

Shaw, T., Youngblood, D. (2017). Cold War Sport, Film, and Propaganda: A Comparative Analysis of the Superpowers. In J. of Cold War Studies. Vol. 19. No. 1, pp. 160-192. DOI 10.1162/JCWS_a_00721.

Stevens, J. W. (2010). God-Fearing and Free: A Spiritual History of America's Cold War. Cambridge, MA, Harvard Univ. Press. 448 p.

Strada, M. J., Troper, H. R. (1997). Friend or Foe? Russians in American Film and Foreign Policy, 1933-1991. Lanham, Scarecrow Press. 278 p. 